\title{
EVALUASI PELAKSANAAN STANDAR PELAYANAN MINIMAL (SPM) FARMASI KATEGORI LAMA WAKTU TUNGGU PELAYANAN RESEP PASIEN RAWAT JALAN DI RUMAH SAKIT ADVENT MANADO
}

\section{EVALUATION OF IMPLEMENTATION ON PHARMACEUTICAL MINIMUM SERVICE STANDARDS (MSS) OF THE PRESCRIPTION WAITING TIME CATEGORY FOR OUTPATIENT SERVICES IN ADVENT HOSPITAL MANADO}

\author{
Esron Eliazar Toreh ${ }^{1)}$, Widya Astuty Lolo ${ }^{1)}$, Olvie S. Datu ${ }^{1)}$ \\ ${ }^{1)}$ Program Studi Farmasi FMIPA UNSRAT Manado, 95115
}

\begin{abstract}
The practice of pharmaceutical services was an integrated activity with the aim of identifying, preventing and resolving drug-related problems and health related problems. The need to evaluated the waiting time for prescription services in pharmaceutical installations was to found out the weaknesses that can prolong prescription services, so that improvements can be made immediately in order to improved the quality of pharmaceutical services. The aim of this study was to evaluated the length of waiting time for nonconcoction drugs and concoction drugs at the Advent Hospital Manado pharmacy installation in October 2019 - January 2020. This research was a non-experimental descriptive study used quantitative and qualitative methods. Sampling was carried out by the nonprobability sampling method. Quantitatively data was taken by direct observation while implementing prescription service at hospital pharmacy installations and qualitatively data was taken by structured interviews to pharmacists in charge and pharmacy staff at outpatient hospital pharmacy installations. The results showed that the average for non-concoction drug prescription service was 20 minutes 29 seconds and for concoction drug prescription service was 26 minutes 26 seconds. The conclusion that the Advent Hospital Manado has met the standards set by the Ministry of Health of the Republic of Indonesia.
\end{abstract}

Keywords: Waiting Time Prescription, Drug Prescription Service, Pharmacy Installation.

\begin{abstract}
ABSTRAK
Praktek pelayanan kefarmasian merupakan kegiatan yang terpadu dengan tujuan untuk mengidentifikasi, mencegah dan menyelesaikan masalah terkait obat dan masalah yang berhubungan dengan kesehatan. Perlunya dilakukan evaluasi terhadap waktu tunggu pelayanan resep di instalasi farmasi adalah untuk mengetahui kelemahan-kelemahan yang dapat memperlama pelayanan resep, sehingga dapat segera dilakukan perbaikan dalam rangka meningkatkan kualitas pelayanan kefarmasian. Penelitian ini bertujuan untuk mengetahui lama waktu tunggu pelayanan resep obat jadi dan obat racikan di Instalasi Farmasi Rumah Sakit Advent Manado pada bulan Oktober 2019 - Januari 2020. Penelitian ini merupakan penelitian deskriptif non eksperimental dengan menggunakan metode kuantitatif dan kualitatif. Pengambilan sampel dilaksanakan dengan metode non-probability sampling. Data yang diambil secara kuantitatif adalah dengan pengamatan langsung saat pelaksanaan pelayanan resep obat di Instalasi Farmasi Rumah Sakit dan data yang diambil secara kualitatif adalah dengan wawancara terstruktur kepada apoteker penanggung jawab dan tenaga kefarmasian di Instalasi Farmasi Rumah Sakit rawat jalan. Hasil penelitian menunjukkan bahwa ratarata untuk pelayanan resep obat jadi 20 menit 29 detik dan rata-rata pelayanan resep obat racikan 26 menit 26 detik. Kesimpulannya bahwa Rumah Sakit Advent Manado telah memenuhi standar yang telah ditetapkan oleh Departemen Kesehatan Republik Indonesia.
\end{abstract}

Kata Kunci: Waktu Tunggu Resep, Pelayanan Resep Obat, Instalasi Farmasi. 


\section{PENDAHULUAN}

Tuntutan pasien dan masyarakat akan mutu pelayanan farmasi mengharuskan adanya perubahan pelayanan dari paradigma lama (drug oriented) ke paradigma baru (patient oriented) dengan filosofi Pharmaceutical Care (pelayanan kefarmasian). Praktek pelayanan kefarmasian merupakan kegiatan yang terpadu dengan tujuan untuk mengidentifikasi, mencegah dan menyelesaikan masalah terkait obat dan masalah yang berhubungan dengan kesehatan (Kepmenkes RI, 2004). Pelayanan farmasi di rumah sakit merupakan suatu kegiatan yang menunjang terlaksananya pelayanan kesehatan yang bermutu bagi pasien. pelayanan kefarmasian di rumah sakit merupakan bagian yang tidak terpisahkan dari sistem pelayanan rumah sakit yang berorientasi kepada pelayanan pasien, penyediaan sediaan farmasi, alat kesehatan dan bahan medis habis pakai yang bermutu dan terjangkau bagi semua lapisan masyarakat termasuk pelayanan farmasi klinik (Permenkes RI, 2016).

Standar Pelayanan Minimal (SPM) adalah spesifikasi teknis tentang tolak ukur pelayanan minimum yang diberikan oleh Badan Layanan Umum kepada masyarakat. SPM di Rumah Sakit yang menyangkut kefarmasian terbagi dalam beberapa kriteria yaitu waktu tunggu pelayanan obat jadi dan obat racikan, tidak adanya kejadian kesalahan pemberian obat, kepuasan pelanggan dan penulisan resep sesuai formularium (Kepmenkes RI, 2008).

Penelitian yang di lakukan oleh Septini (2012) yang di laksanakan di RSPAD Gatot Soebroto didapatkan rata-rata waktu tunggu untuk resep non racikan selama 39 menit dan resep racikan 60,4 menit, dimana hal ini tidak sesuai standar yang telah ditetapkan oleh Departemen Kesehatan Republik Indonesia yaitu $\leq 30$ menit untuk resep obat jadi (non racikan) dan $\leq 60$ menit untuk resep racikan.
Penelitian yang dilakukan oleh Nurjanah, et al., (2016) di Apotek pelengkap Kimia Farma BLU di Rumah Sakit Prof. DR. R.D. Kandou Manado diketahui bahwa waktu tunggu pelayanan resep obat jadi adalah 16 menit 08 detik. Waktu tunggu pelayanan resep racikan 39 menit 07 detik maka didapatkan gambaran bahwa hal ini telah sesuai standar yang ditetapkan oleh Departemen Kesehatan Republik Indonesia yaitu $\leq 30$ menit untuk resep obat jadi (non racikan) dan $\leq 60$ menit untuk resep racikan. Berdasarkan penelitian Setyowati, et al., (2017), perlunya dilakukan evaluasi terhadap waktu tunggu pelayanan resep di instalasi farmasi adalah untuk mengetahui kelemahan-kelemahan yang dapat memperlama pelayanan resep, sehingga dapat segera dilakukan perbaikan dalam rangka meningkatkan kualitas pelayanan kefarmasian. Berdasarkan hasil penelitian tersebut, peneliti bermaksud melakukan penelitian untuk mengevaluasi dan melihat gambaran umum Standar Pelayanan Minimal (SPM) yang terkait lama waktu tunggu resep obat di Rumah Sakit Advent Manado.

\section{METODOLOGI PENELITIAN}

\section{Waktu dan Tempat Penelitian}

Penelitian ini dilakukan di Instalasi Farmasi Rumah Sakit Advent Manado pada bulan Oktober 2019 - Juni 2020.

\section{Bentuk Penelitian}

Penelitian ini merupakan penelitian deskriptif yang dilakukan dengan metode penelitian kuantitatif dan kualitatif. Metode kuantitatif yang dimaksud ialah data dari jumlah lama waktu tunggu pelayanan resep obat jadi maupun obat racikan akan langsung di masukkan kedalam formulir pencatatan waktu, sedangkan dengan metode kualitatif akan dilaksanakan dengan melakukan pengamatan dan wawancara langsung kepada 
kepala Instalasi Farmasi Rumah Sakit di Rumah Sakit Advent Manado.

\section{Populasi Penelitian}

\section{Populasi}

Populasi yang akan diambil oleh peneliti untuk penelitian ini yaitu seluruh resep obat pasien rawat jalan atau pendampingnya yang menerima pelayanan kefarmasian di Instalasi Farmasi Rumah Sakit Advent Manado di Manado pada bulan November 2019 - Januari 2020. Jumlah Populasi di Rumah Sakit Advent Manado selama 3 bulan terakhir memiliki rata-rata 100 resep setiap hari dan didapatkan populasi selama 3 bulan yaitu 8.400 resep

\section{Sampel}

Pengambilan sampel menggunakan metode nonprobability sampling. Jumlah populasi yang telah diketahui yaitu sebanyak 8.400 resep kemudian digunakan rumus slovin untuk penentuan jumlah sampel yang akan digunakan. Untuk menghitung berapakah jumlah sampel yang diperlukan dalam penelitian ini maka rumusnya ialah:.

$$
n=\frac{N}{1+N e^{2}}
$$

$\mathrm{n} \quad=$ Jumlah Sampel yang diambil

$\mathrm{N}=$ Jumlah Populasi

e $\quad=$ Presentase kesalahan sampel, $\mathrm{e}=0.05$ $(5 \%)$

$$
\begin{gathered}
n=\frac{8.400}{1+8.400(0.05)^{2}} \\
n=\frac{8.400}{22} \\
n=381 \text { Resep }
\end{gathered}
$$

Berdasarkan hasil perhitungan tersebut maka sampel yang digunakan minimal sebanyak 381 resep.

\section{Alat dan Bahan}

Alat

Alat yang digunakan dalam penelitian ini, antara lain: stopwatch, alat tulis (kertas, pensil, penghapus, dan lain-lain), alat perekam suara dan lembar formulir pencatatan waktu tunggu.

\section{Bahan}

Bahan yang digunakan dalam penelitian ini, antara lain: informasi tertulis dari waktu tunggu yang tertera di lembar formulir pencatatan lama waktu tunggu dan hasil wawancara terstruktur dari apoteker Instalasi Farmasi Rumah Sakit Advent Manado

\section{Pengumpulan Data}

\section{Perhitungan Lama Waktu Tunggu Pelayanan Resep}

Pengumpulan data untuk perhitungan lama waktu tunggu pelayanan resep obat dilaksanakan dengan cara observasi langsung saat pelaksanaan pelayanan resep dan kemudian dihitung rentang waktu saat resep diserahkan oleh pasien hingga saat resep diserahkan kembali kepada pasien

\section{Wawancara Terstruktur}

Wawancara terstruktur dilaksanakan dengan wawancara langsung kepada Apoteker yang bertanggung jawab di Instalasi Farmasi Rumah Sakit Advent Manado untuk memperoleh data dalam membahas hasil yang telah diperoleh oleh peneliti.

\section{Analisis Data}

Data yang telah diperoleh dari tenggang waktu yang dimulai dari pasien menyerahkan resep sampai dengan pasien telah menerima obat jadi dan tenggang waktu 
yang dimulai dari pasien menyerahkan resep sampai pasien telah menerima obat racikan kemudian dianalisis untuk ditentukan data mana yang menjadi nilai minimum, nilai maksimum, nilai rata-rata, dan nilai standar deviasi. Nilai rata-rata yang telah didapat tersebut kemudian dibandingkan dengan Standar Pelayanan Minimal (SPM) dalam hal ini batas lama waktu tunggu pelayanan obat jadi dan racikan yang telah ditetapkan oleh Departemen Kesehatan Republik Indonesia. Data yang diperoleh dari wawancara langsung kepada kepala Instalasi Farmasi Rumah Sakit akan dimasukkan kedalam pembahasan.

\section{HASIL DAN PEMBAHASAN}

\section{Waktu Tunggu Pelayanan Resep Obat}

Tabel 1. Jumlah Resep, Jumlah Rata-rata Item Obat dan Total Waktu Tunggu Menurut Jenis Resep

\begin{tabular}{ccc}
\hline Indikator & $\begin{array}{c}\text { Pelayanan } \\
\text { Resep Obat } \\
\text { Jadi }\end{array}$ & $\begin{array}{c}\text { Pelayanan } \\
\text { Resep Obat } \\
\text { Racikan }\end{array}$ \\
\hline $\begin{array}{c}\text { Jumlah resep } \\
\text { yang di } \\
\text { survey }\end{array}$ & 382 & 16 \\
\hline $\begin{array}{c}\text { Jumlah rata- } \\
\text { rata item obat } \\
\text { dalam resep }\end{array}$ & 3 & 2 \\
\hline $\begin{array}{c}\text { Total Waktu } \\
\text { (menit) }\end{array}$ & 7827,15 & 418,31 \\
\hline
\end{tabular}

Subyek pada penelitian ini yaitu resep obat jadi dan resep obat racikan. Berdasarkan hasil penelitian yang dilakukan, diketahui rata-rata jumlah obat yang diresepkan adalah 2-3 item obat untuk resep obat jadi dan 1-2 item obat untuk resep obat racikan. Pencatatan waktu tunggu pelayanan resep obat jadi maupun obat racikan digunakan stopwatch untuk menghitung waktunya. Pencatatan waktu tunggu resep obat jadi maupun obat racikan di rekap setiap hari di lembar khusus yaitu formulir pencatatan lama waktu tunggu dimana didapatkan sebanyak
382 resep obat jadi 16 obat racikan selama pelaksanaan penelitian. Total waktu kumulatif yang didapatkan sepanjang pelaksanaan penelitian adalah selama 7827,15 menit untuk resep obat jadi dan 418,31 menit untuk resep obat racikan

\section{Waktu Tunggu Pelayanan Resep Obat Jadi dan Obat Racikan}

Evaluasi terdahap standar pelayanan minimal (SPM) farmasi kategori lama waktu tunggu pelayanan resep obat yaitu dilakukan penghitungan jumlah kumulatif waktu yang dimulai saat pasien menyerahkan resep kebagian IFRS rawat jalan dan berakhir saat pasien menerima obatnya. Penghitungan apoteker berdasarkan beban kerjanya pada pelayanan kefarmasian di rawat jalan yang meliputi pelayanan farmasi manajerial dan pelayanan farmasi klinik dengan aktivitas pengkajian resep, penyerahan obat, pencatatan penggunaan obat (PPP) serta konseling, idealnya dibutuhkan tenaga apoteker dengan rasio 1 apoteker untuk 50 pasien (Permenkes RI, 2016)

Tabel 2. Standar deviasi, rata-rata, median, maksimum, dan minimum total waktu tunggu menurut jenis resep

\begin{tabular}{ccc}
\hline Indikator & $\begin{array}{c}\text { Pelayanan } \\
\text { Resep Obat } \\
\text { Jadi (menit) }\end{array}$ & $\begin{array}{c}\text { Pelayanan } \\
\text { Resep Obat } \\
\text { Racikan } \\
\text { (menit) }\end{array}$ \\
\hline $\begin{array}{c}\text { Standar } \\
\text { Deviasi }\end{array}$ & 14,25 & 15,25 \\
\hline Rata-rata & 20,29 & 26,26 \\
\hline Median & 16,14 & 21,47 \\
\hline Maksimm & 77,18 & 63,23 \\
\hline Minimum & 3,01 & 8,20 \\
\hline
\end{tabular}

Tabel 2 menunjukkan bahwa untuk pelayanan resep obat jadi memiliki standar deviasi yaitu 14,25 menit dan dengan rataratanya ialah selama 20,29 menit. Hal ini membuktikan bahwa pelayanan resep obat dirumah sakit ini sudah diusahakan secara optimal, yang dapat dilihat juga bahwa 
pelayanan resep obat jadi pernah menyentuh waktu hanya selama 3,01 menit saat peneliti melaksanakan penelitian.

Hasil penelitian ini memberikan gambaran bahwa pelayanan resep obat jadi kepada pasien sudah cukup baik, walaupun masih didapatkan data bahwa pernah beberapa kali pelayanan resep tersebut melebih batas waktu yang ditetapkan oleh Departemen Kesehatan Republik Indonesia. Hal ini dapat dilihat bahwa nilai maksimum yang didapatkan adalah sebesar 1 jam 17 menit 18 detik yang dikarenakan pelayanan resep obat tersebut dilaksanakan di jam sibuk dimana pasien memang menumpuk. Berdasarkan penelitian yang dilakukan oleh Wijaya (2012), lama waktu tunggu pelayanan resep obat dipengaruhi beberapa faktor yaitu sumber daya manusia, jenis pasien, jenis resep, ketersediaan obat, peresepan dokter, sarana dan prasarana, formularium obat, standar operating procedure (SOP) pelayanan resep. Faktor proses pelayanan resep meliputi penerimaan resep, pemberian harga obat, pembayaran, pengambilan dan peracikan obat, pemberian etiket obat, dan penyerahan obat kepada pasien.

Hasil wawancara yang dilakukan kepada apoteker penanggung jawab yang menyangkut hubungan antara pengalaman kerja dengan kecepatan pelayanan resep diketahui bahwa jika tenaga farmasi yang bertugas telah memiliki bekal pendidikan kefarmasian dan telah terbukti berkompetensi serta sudah bekerja cukup lama dibagian tersebut maka akan sangat mempengaruhi kecepatan pelayanan resep kepada pasien. Hal tersebut juga dibuktikan dengan penelitian yang dilakukan oleh Septini (2012), didapatkan bahwa diperlukan tenaga yang memiliki latar belakang pendidikan farmasi dan dengan pengalaman kerja yang cukup lama sehingga dapat mempersingkat waktu dalam pelayanan resep obat kepada pasien.

Pengalaman kerja setiap individu juga berpengaruh dimana semakin lama seseorang bekerja, maka akan semakin terampil serta semakin menambah wawasan dan kematangan dalam melaksanakan tugasnya (Puspitasari 2011). Berdasarkan penelitian yang dilakukan oleh Prabandari, et al., (2019), jumlah tenaga farmasi merupakan salah satu pendukung terciptanya pelayanan kefarmasian dengan maksimal sehingga membuat waktu tunggu pasien dalam menerima obat tidak lama

Tabel 2 juga menunjukkan bahwa pelayanan resep obat racikan memiliki standar deviasi yaitu 15,25 menit dan memiliki ratarata selama 26,26 menit. Data yang didapatkan saat pelaksanaan pelayanan resep obat racikan pernah melewati standar yang telah ditetapkan oleh Departemen Kesehatan Republik Indonesia yaitu selama 1 jam 03 menit 23 detik, hal tersebut terjadi karena resep tersebut diserahkan pada jam sibuk sehingga terjadi penumpukkan jumlah resep yang belum terlayani.

Waktu tunggu pelayanan obat racikan juga memakan waktu lebih lama dibandingkan dengan pelayanan resep nonracikan (obat jadi) dikarenakan memerlukan waktu lebih dalam penghitungan dosis obat, penimbangan bahan obat, serta melakukan proses peracikan baik dalam bentuk puyer kapsul maupun sediaan lainnya (Karuniawati, et al., 2016).

Berdasarkan hasil wawancara yang dilakukan peneliti terkait pengaruh pengetahuan dan kemampuan dari pegawai yang bekerja di IFRS terhadap lamanya pelayanan resep dan pengaruhnya dalam mempersingkat waktu pelayanan resep. Hasil wawancara menunjukkan bahwa pengetahuan dan kemampuan pegawai yang bekerja di 
IFRS bagian rawat jalan bebanding lurus dengan kecepatan pelayanan resep, artinya semakin tinggi pengetahuan dan kemampuan pegawai tersebut maka akan semakin cepat waktu pelayanan resep.

Berdasarkan penelitian yang dilaksanakan oleh Mohebbifar, et al., (2014), yaitu sumber daya manusia adalah satu faktor yang sangat berpengaruh dalam mempersingkat lama waktu tunggu pelayanan resep obat dimana sumber daya manusia yang kurang terampil dan professional akan menyebabkan durasi pelayanan semakin lama. Sebaliknya, ketersediaan sumber daya manusa yang cukup terampil, lama kerja, beban kerja dan pengetahuan pegawai akan sangat mempengaruhi lama waktu tunggu pelayanan resep obat.

Tabel 3. Perbandingan rata-rata waktu tunggu resep yang diperoleh dan standar yang ditetapkan oleh DEPKES RI

\begin{tabular}{lcc} 
Jenis Resep & $\begin{array}{c}\text { Rata-rata } \\
\text { Waktu } \\
\text { Tunggu } \\
\text { Resep } \\
\text { (menit) }\end{array}$ & $\begin{array}{c}\text { Standar } \\
\text { Departemen } \\
\text { Kesehatan } \\
\text { RI } \\
\text { (menit) }\end{array}$ \\
\hline Obat Jadi & 20,29 & $\leq 30$ \\
\hline Obar Racikan & 26.26 & $\leq 60$ \\
\hline \multicolumn{3}{c}{ Tabel 3 menunjukkan bahwa rata-rata } \\
waktu tunggu yang didapatkan untuk \\
pelayanan resep obat jadi adalah selama 20,29 \\
menit. Hal tersebut sudah sesuai yang \\
ditetapkan oleh Departemen Kesehatan \\
Republik Indonesia yaitu $\leq 30$ menit. Rata- \\
rata waktu tunggu yang didapatkan untuk \\
pelayanan resep obat racikan yaitu selama \\
26,26 menit dimana hal tersebut juga sudah \\
memenuhi standar yang telah ditetapkan yaitu \\
$\leq 60$ menit. Rumah Sakit Advent Manado \\
telah dapat memenuhi standar yang telah \\
ditetapkan.
\end{tabular}

\section{KESIMPULAN}

Rumah Sakit Advent Manado telah dapat memenuhi standar pelayanan minimal (SPM) farmasi yang telah ditetapkan oleh Departemen Kesehatan Republik Indonesia. Hal ini dibuktikan dengan rata-rata waktu tunggu yang didapat untuk resep obat jadi adalah selama 20 menit 29 detik dimana hal tersebut sudah sesuai karna tidak melebih waktu yang ditetapkan yaitu maksimal 30 menit dan untuk rata-rata waktu tunggu resep obat racikan didapatkan selama 26 menit 26 detik dimana hal tersebut tidak melewati standar waktu yang telah ditetapkan yaitu maksimal 60 menit.

\section{SARAN}

Disarankan bagi peneliti selanjutnya untuk melakukan penelitian terkait hubungan kepuasan pasien dengan lamanya waktu tunggu pelayanan resep obat jadi dan resep obat racikan di rumah sakit.

\section{DAFTAR PUSTAKA}

Karuniawati, H., Hapsari, I.G., Arum, M., Aurora, A.T., Wahyono, N.A. 2016. Evaluasi Pelaksanaan Standar Pelayanan Minimal (SPM) Farmasi Kategori Lama Waktu Tunggu Pelayanan Resep Pasien Rawat Jalan Di RSUD Kota Salatiga. Jurnal Ilmiah Farmasi. 4(1): 20-25.

Keputusan Menteri Kesehatan Republik Indonesia. 2004. Standar Pelayanan Farmasi Di Rumah Sakit. Departemen Kesehatan Republik Indonesia, Jakarta. 
Keputusan Menteri Kesehatan Republik Indonesia. 2008. Standar Pelayanan Minimal Rumah Sakit. Departemen Kesehatan Republik Indonesia, Jakarta.

Mohebbifar, R., Hasanpoor, E., Mohseni, M., Sokhanvar, M., Khosravizadeh, O., Isfahani, H.M. 2014. Outpatient Waiting Time in Health Services and Teaching Hospital : A Case Study in Iran. Global Journal of Health Science. 6(1): 172-180.

Nurjanah, I., Maramis, F.R.R., Engkeng, S. 2016. Hubungan Antara Waktu Tunggu Pelayanan Resep Dengan Kepuasan Pasien Di Apotek Pelengkap Kimia Farma BLU Prof. DR. R.D. Jurnal Ilmiah Farmasi. 5(1): 362-370.

Peraturan Menteri Kesehatan Republik Indonesia. 2016. Standar Pelayanan Kefarmasian Di Rumah Sakit. Departemen Kesehatan Republik Indonesia, Jakarta

Prabandari, S., Prabasiwi, A. 2019. Analisis Waktu Tunggu Pelayanan Obat Di Puskesmas Wilayah Kota Tegal (Berdasarkan Peraturan Menteri Kesehatan No.74 Tahun 2016). Jurnal Farmasi Galenika. 6(3).

Puspitasari, A. 2011. Analisis Waktu Tunggu Pelayanan Resep Pasien Umum di Depo Farmasi Rawat Jalan RS. Karya Bhakti Tahun 2011 [Tesis]. Universitas Indonesia, Depok.

Septini, R. 2012. Analisis Waktu Tunggu Pelayanan Resep Pasien Akses Rawat Jalan Di Yanmasum Farmasi RSPAD Gatot Soebroto Tahun 2011 [Tesis]. Universitas Indonesia, Depok.
Setyowati, E., Etikasari, R., Tetuko, A. 2017. Analisa Lamanya Waktu Pelayanan Resep Racikan Di Instalasi Farmasi Rawat Jalan Rumah Sakit Islam Kendal. Jurnal Farmasi. 2(1): 1-6.

Wijaya, H. 2012. Analisis Pelaksanaan Standar Pelayanan Minimal (SPM) Rumah Sakit Bidang Farmasi Di Instalasi Farmasi RS Tugu Ibu Tahun 2012 [Tesis]. Universitas Indonesia, Depok. 